Rapp. Grønlands geol. Unders. 99, 25-32 (1980)

\title{
THE ZIG-ZAG DAL BASALT FORMATION, NORTH GREENLAND
}

\author{
H. F. Jepsen, F. Kalsbeek and R.J. Suthren
}

The Zig-Zag Dal Basalt Formation is a new formation named after a valley in the central part of Mylius-Erichsen Land (fig. 11). The occurrence of volcanic rocks in this region was first reported by the Greenarctic Consortium in 1969 (personal communication to GGU), and the first description of the basaltic sequence was published by Jepsen \& Kalsbeek (1979).

Although Haller (1971) did not mention the existence of volcanic rocks in his description of the sedimentary sequence from the Hagen Fjord (fig. 11) area, it can be concluded from Haller's fig. 23 that the lower boundary of his Hagen Fjord Group corresponds to the lower boundary of the Zig-Zag Dal Basalt Formation.

\section{Distribution, boundaries and thickness}

The type locality of the Zig-Zag Dal Basalt is situated on the north-western side of Zig-Zag Dal, Mylius-Erichsen Land, where a composite section was measured (figs 11 and 12 , sections 91 and 96). Most of the formation, together with its lower contact, is visible in type section 96. However, the upper boundary is defined from section 91 .

The Zig-Zag Dal Basalt overlies, conformably, the Proterozoic Independence Fjord Group, Fiil Fjord Member (Collinson, this report) and it is overlain by the basal sandstone association, of probable Proterozoic age, of the Campanuladal Formation (Clemmensen, 1979). This upper boundary is a peneplained surface.

The basalt is located in central Mylius-Erichsen Land and in the eastern part of J. C. Christensen Land (fig. 11) and covers an area of about $10000 \mathrm{~km}^{2}$. Its thickness varies between approximately $100 \mathrm{~m}$ (Danmark Fjord (fig. 11), section 159 and Independence Fjord (fig. 11), section 0) and $1350 \mathrm{~m}$ at the type sections in Zig-Zag Dal.

About $100 \mathrm{~km}$ north of Independence Fjord at Hellefiskefjord $\left(82^{\circ} 50^{\prime} \mathrm{N}, 24^{\circ} \mathrm{W}\right)$, approximately $200 \mathrm{~km}^{2}$ of the Zig-Zag Dal Basalt is exposed in an uplifted fault block. Here the basalt (500 $\mathrm{m}$ thick) overlies the Independence Fjord Group and is overlain, unconformably, by the upper Carboniferous Foldedal Formation (Håkansson, 1979).

The Independence Fjord Group, underlying the Zig-Zag Dal Basalt, is intruded by numerous sills, sheets and dykes of dolerite and more siliceous rocks (Jepsen \& Kalsbeek, 1979). The stratigraphical position of the basalts makes it likely that they have the same age as the intrusive rocks, which have given $\mathrm{Rb}-\mathrm{Sr}$ whole-rock isochron ages of $c .1250 \mathrm{~m}$. $\mathrm{y}$.

\section{Lithology}

In sections 91 and 96 (fig. 11) the Zig-Zag Dal Basalt was measured in detail and a sequence of flows (arbitrarily numbered from 49 to 79 ), or flow-units, were defined. In addition, 11 other sections were measured in the area between Independence Fjord and 


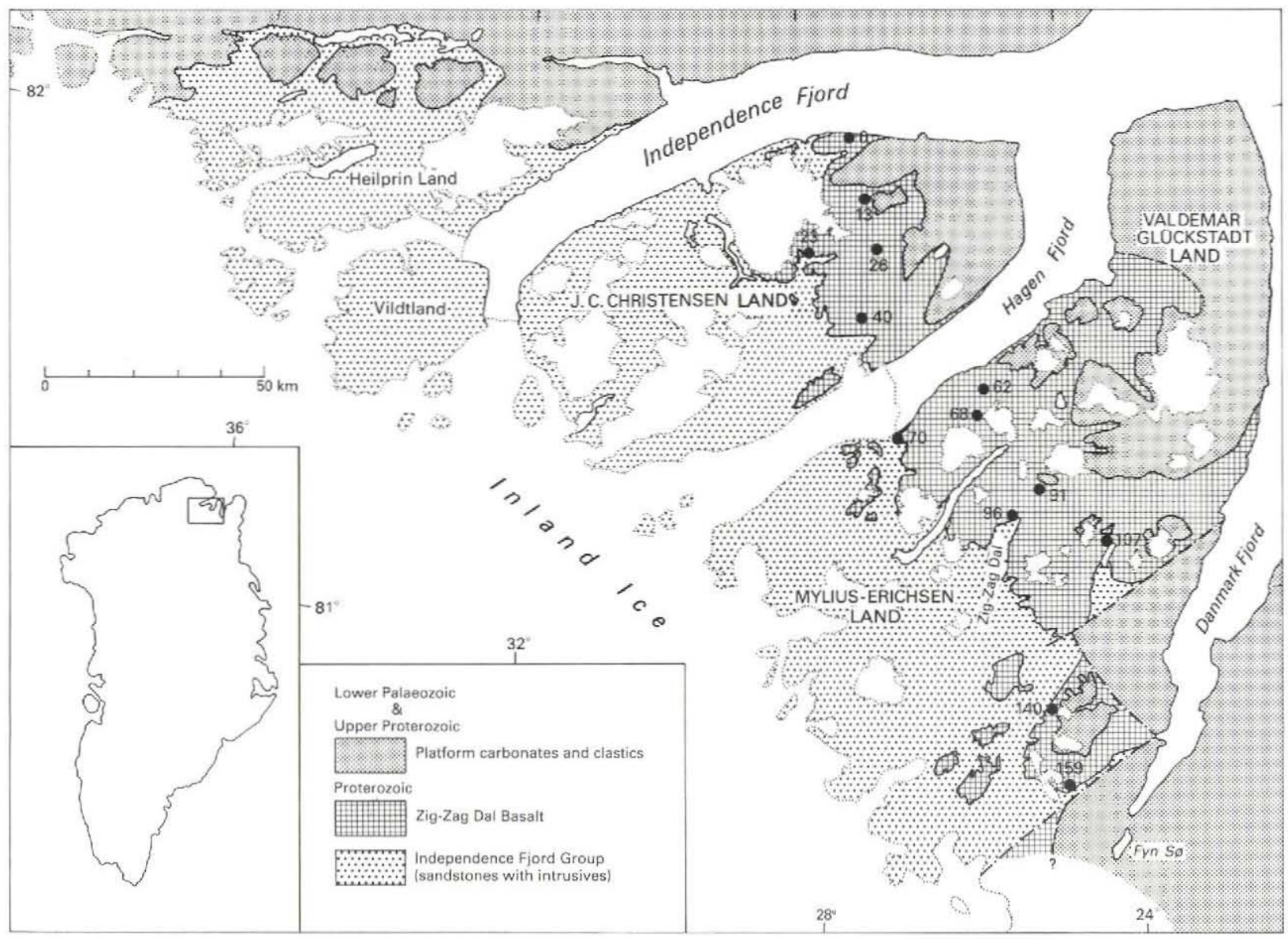

Fig. 11. Map showing the main area of the Proterozoic Zig-Zag Dal Basalt in the platform area of eastern North Greenland. The Hellefiskefjord area, where about $200 \mathrm{~km}^{2}$ of the basalt is exposed in an uplifted fault block north of the Palaeozoic platform, is situated approximately $100 \mathrm{~km}$ north of Independence Fjord. Sections measured through the basalt sequence are indicated on the map (see also fig. 12). 


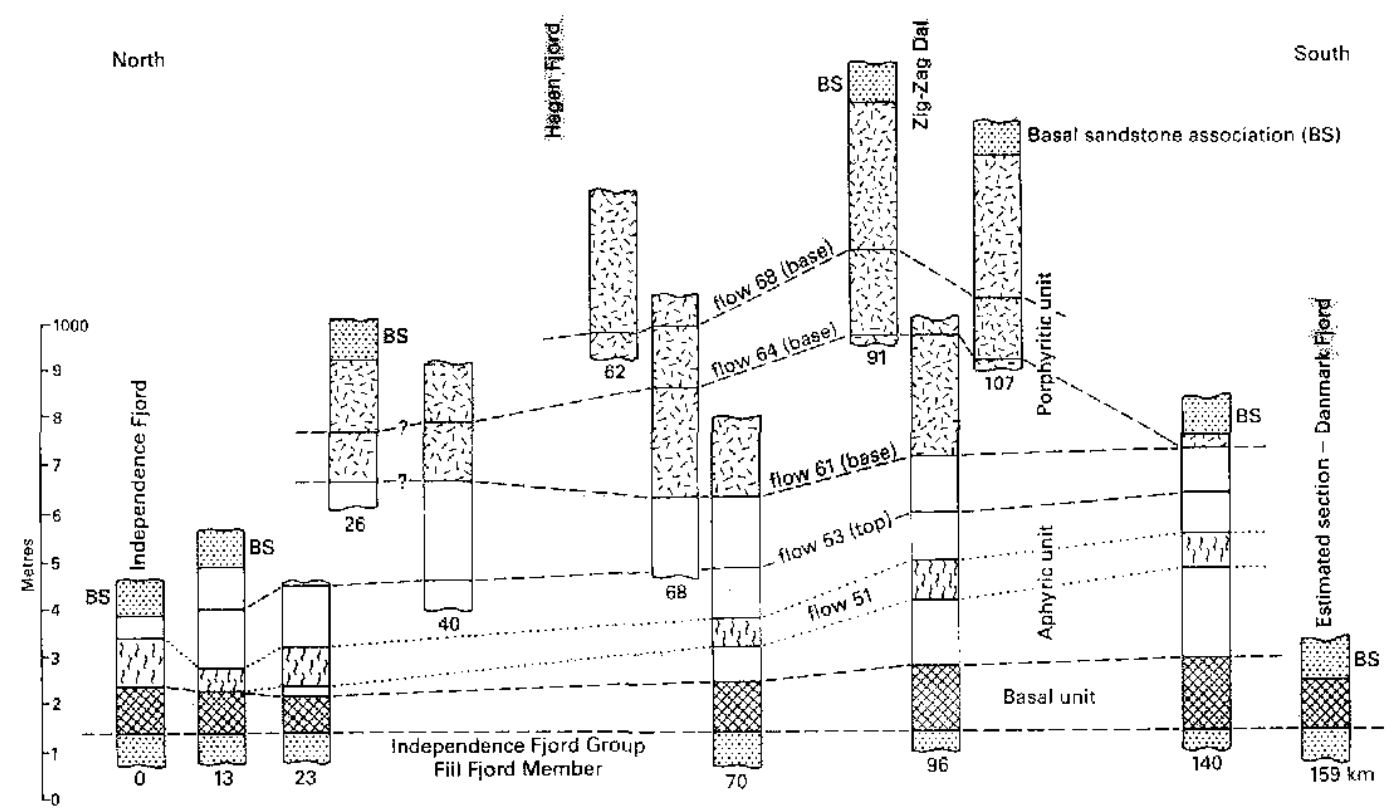

Fig. 12. Summary of sections measured through the Zig-Zag Dal Basalt. Basalt flows referred to in the text are shown in the figure.

Danmark Fjord (fig. 11). In the following, a general description is given of the most characteristic lithological and structural aspects of the sequence and fig. 12 shows the correlation between the sections.

The Zig-Zag Dal Basalt can be divided into three units. These are, in ascending order: basal unit, aphyric unit and porphyritic unit.

\section{Basal unit}

The basal unit (100 to $120 \mathrm{~m}$ thick) is composed of small lenticular aphyric basalt flows, varying in thickness from $20 \mathrm{~cm}$ to $10 \mathrm{~m}$. The individual flows cannot be traced from section to section. The lower 10-20 m, found in sections 23 and 140, are composed of pillow lavas. A thin sediment horizon (sandstone and dolomite) overlies the basal unit at sections 13 and 140 and has a thickness of 1 to $10 \mathrm{~m}$. The uniform thickness of the basal unit suggests that there was no extensive erosion before the deposition of the overlying sediments. The limitcd extent of individual flows indicates volcanic activity over a wide area, at a number of eruptive centres.

The occurrence of pillow lavas suggest a subaqueous effusion of at least the lowest part of the basal unit, and contrasts with the overlying aphyric and porphyric units which probably formed subaerially. 


\section{Aphyric and porphyritic units}

The aphyric unit (390 to $440 \mathrm{~m}$ thick) and the porphyritic unit (up to $750 \mathrm{~m}$ thick) are, together, composed of about 30 flows varying in thickness from $10 \mathrm{~m}$ to $120 \mathrm{~m}$. Some of the thicker flows can be traced through all the measured sections. Most flows have vesicular, amygdaloidal or flow-brecciated tops preserved. Some flow tops show evidence of limited reworking, in the form af a conglomerate of rounded, or subrounded, basalt cobbles and pebbles. These essentially non-erosional tops probably indicate that there were only short time intervals between the deposition of the individual flows.

Flow characteristics are weathering colour, type of columnar jointing, and the presence or absence of phenocrysts and vesicular cognate inclusions. These characteristics enable correlation of flows from section to section.

Within the aphyric unit, one flow (no. 51) can be traced through all the sections. It is a dark, fine-grained basalt and varies in thickness between $40 \mathrm{~m}$ (section 13) and $105 \mathrm{~m}$ (section 0 ). Its minimum volume is $600 \mathrm{~km}^{3}$. In its central part it is orange-weathering and has a characteristic curvilinear columnar jointing. In the northern part of the area this flow rests directly on the basal unit, whereas it lies $180 \mathrm{~m}$ above the top of the basal unit, in section 140 , in the southern part of the area. This suggests that the relatively thin flows between the basal unit and flow 51 die out towards the north. The overlying flow (no. 52) is characterized by a distinctive dark brown colour. It varies in thickness from $35 \mathrm{~m}$ to $20 \mathrm{~m}$ and can be followed between section 140 and section 70 .

At the base of section $26,50 \mathrm{~m}$ below the porphyritic unit, the top of a red rhyolitic flow-unit is found and can be followed for about $15 \mathrm{~km}$ north-east of the section. It is exposed over an area of approximately $70 \mathrm{~km}^{2}$ and at its maximum, $6 \mathrm{~km}$ north-east of section 26, it attains a thickness of about $100 \mathrm{~m}$ and includes at least three flows. In some parts it contains centimetre-large flow-oriented gas cavities filled with quartz and calcite.

The aphyric unit is normally overlain by a cliff-forming flow (no. 61), up to $120 \mathrm{~m}$ thick, containing glomerocrysts of plagioclase and clinopyroxene crystals. At least 12 of the overlying flows comprising the porhpyritic unit also contain phenocrysts.

Within the porphyritic unit flows no. 64 and 68 can be traced through several sections. Flow 64 (up to $100 \mathrm{~m}$ thick) is characterized by orange-weathering and the development of curvilinear columnar jointing in the central part. It contains glomerocrysts of plagioclase. Flow 68 is a prominent cliff-forming flow of up to about $100 \mathrm{~m}$ thick, and in its lower part is characterized by a red-brown weathering colour. It is glomerophyric (plagioclase) and contains centimetre-sized vesicular cognate inclusions of more coarse-grained basalt.

The interval between the top of the aphyric unit and the base of flow 64 changes character laterally, and the thickness varies from 0 to $260 \mathrm{~m}$. The flows in this interval are relatively thin and cannot be traced from section to section. Towards the top of the interval there is an increasing amount of conglomerate, sandstone and dolomite between the flows, and tuffs, up to $50 \mathrm{~m}$ thick, are found in several sections. In section 68 thin pillow lava horizons are present within the tuffs and local erosional relief of up to $50 \mathrm{~m}$ is excavated in the flows underlying the tuffs in section 91 . 


\section{Petrography}

The groundmass mineralogy does not show any systematic variation between the three units. The grain size of the rocks varies between $0.2 \mathrm{~mm}$ and $0.6 \mathrm{~mm}$, with the clinopyroxenes making up larger $(2$ to $3 \mathrm{~mm}$ ) ophitic crystals in places. Yellow or brown palagonite has only been observed in a few thin sections. The brown flow 52 contains several per cent of reddish cryptocrystalline quartzo-feldspathic interstitial matrix.

The major constituents of the groundmass are plagioclase, clinopyroxenes (pigeonite and augite) and opaque material. Orthorhombic pyroxene has not been found. Olivine, always altered to greenish or yellowish iddingsite, is present in about half of the flows with a slight tendency to be more abundant in the basal unit. Olivine may comprise up to $c .15$ per cent of the rock.

Phenocrysts in the porphyritic unit are plagioclase (max. 85 per cent anorthite) and clinopyroxenes. The plagioclase phenocrysts occur in clusters with diametres, up to $10 \mathrm{~mm}$, in which single crystals may attain lengths of up to $8 \mathrm{~mm}$. The pyroxenes (1 to $4 \mathrm{~mm}$ ) have a strongly ophitic intergrowth relationship with small plagioclase laths, and a single pyroxene may contain 50 or more plagioclase crystals which often protrude outside the margin of the phenocryst.

Alteration of the basalts varies through the sequence. The plagioclase may be very fresh or completely saussuritised, or altered to a low birefringent pale blue-green fibrous matrix composed of chlorite or serpentine. The pyroxene is mostly fresh but in some thin sections incipient uralitisation has been seen to have taken place along the margin of the crystals. As mentionend above the olivines are invariably replaced by iddingsite.

The basalts from the Hellefiskefjord area have undergone almost complete metamorphic recrystallisation and now present an assemblage of albite-chlorite-epidote-actinolitesphene (R. E. Bevins, personal communication).

The rhyolitic rock in section 26 is composed of more than 50 per cent reddish cryptocrystalline quartzo-feldsphatic matrix which contains microlites of needle-shaped feldspar $(0.2$ to $1.0 \mathrm{~mm}$ long), idiomorphic pyroxene crystals $(0.1$ to $0.3 \mathrm{~mm})$ and opaque material. It also contains amygdales filled with quartz, feldspar and calcite. The pyroxenes are completely replaced by a pale green substance (chlorite, amphibole or serpentine).

\section{Chemistry}

Fifty-nine samples have been analysed for major elements and Table 2 shows average analyses from the three units. Based on normative classification (proposed by Streckeisen \& Le Maitre, 1979) the rocks comprising the basal unit are trachybasalts, the aphyric and the porphyritic units are both basalts, flow 52 is a trachyandesite and the red flow-unit is classified as rhyolite. As this normative classification is based solely on the chemistry of the rocks, the resulting names should be regarded with a certain reservation, because later alteration may have affected, locally, the chemical composition.

Classification according to magma type is demonstrated in fig. 13a and fig. 14, and following the rules as summerised by Irvine \& Baragar (1971) the Zig-Zag Dal Basalt belongs to the olivine-tholeiitic suite. The basal unit shows a slightly deviating trend compared with the overlying units by being relatively rich in $\mathrm{Al}_{2} \mathrm{O}_{3}$ (fig. 14), $\mathrm{Na}_{2} \mathrm{O}$ and $\mathrm{MgO}$ and poor in total iron (fig. $13 \mathrm{~b}$ ) and $\mathrm{CaO}$. This difference might be explained by the subaqueous 
Table 2. Zig-Zag Dal Basalt major element chemistry

\begin{tabular}{|c|c|c|c|c|c|}
\hline $\mathrm{N}$ & $\begin{array}{l}\text { A } \\
7\end{array}$ & $\begin{array}{l}B \\
18\end{array}$ & $\begin{array}{l}\text { C } \\
29\end{array}$ & $\begin{array}{l}D \\
2\end{array}$ & $\begin{array}{l}E \\
3\end{array}$ \\
\hline $\begin{array}{l}\mathrm{SiO}_{2} \\
\mathrm{TiO}_{2} \\
\mathrm{Al}_{2} \mathrm{O}_{3}\end{array}$ & $\begin{array}{r}53.42 \\
0.88 \\
15.76\end{array}$ & $\begin{array}{r}51.88 \\
0.94 \\
14.69\end{array}$ & $\begin{array}{r}50.59 \\
1.09 \\
14.39\end{array}$ & $\begin{array}{r}56.33 \\
1.32 \\
13.65\end{array}$ & $\begin{array}{r}67.47 \\
0.86 \\
12.25\end{array}$ \\
\hline $\begin{array}{l}\mathrm{Fe}_{2} \mathrm{O}_{3} \\
\mathrm{FeO} \\
\mathrm{MnO}\end{array}$ & $\begin{array}{l}3.14 \\
6.58 \\
0.24\end{array}$ & $\begin{array}{l}2.89 \\
7.26 \\
0.22\end{array}$ & $\begin{array}{l}4.13 \\
7.99 \\
0.24\end{array}$ & $\begin{array}{l}3.64 \\
7.81 \\
0.23\end{array}$ & $\begin{array}{l}5.82 \\
0.69 \\
0.08\end{array}$ \\
\hline $\begin{array}{l}\mathrm{MgO} \\
\mathrm{CaO} \\
\mathrm{Na}_{2} \mathrm{O}\end{array}$ & $\begin{array}{r}10.20 \\
4.64 \\
4.12\end{array}$ & $\begin{array}{r}8.25 \\
10.04 \\
2.95\end{array}$ & $\begin{array}{r}7.61 \\
10.84 \\
2.71\end{array}$ & $\begin{array}{l}4.63 \\
6.12 \\
3.68\end{array}$ & $\begin{array}{l}3.13 \\
0.67 \\
1.03\end{array}$ \\
\hline $\begin{array}{l}\mathrm{K}_{2} \mathrm{O} \\
\mathrm{P}_{2} \mathrm{O}_{5}\end{array}$ & $\begin{array}{r}0.90 \\
0.12 \\
100.00\end{array}$ & $\begin{array}{r}0.77 \\
0.11 \\
100.00\end{array}$ & $\begin{array}{r}0.31 \\
0.10 \\
100.00\end{array}$ & $\begin{array}{r}2.42 \\
0.18 \\
100.00\end{array}$ & $\begin{array}{r}7.85 \\
0.17 \\
100.00\end{array}$ \\
\hline $\mathrm{H}_{2} \mathrm{O}^{+}$ & 5.22 & 2.58 & 2.17 & 2.61 & 2.01 \\
\hline $\begin{array}{l}q z \\
c\end{array}$ & & & & $\begin{array}{l}2.7 \\
1.3\end{array}$ & 21.2 \\
\hline $\begin{array}{l}\text { or } \\
a b \\
\text { an }\end{array}$ & $\begin{array}{r}5.2 \\
36.3 \\
21.4\end{array}$ & $\begin{array}{r}4.5 \\
26.5 \\
24.5\end{array}$ & $\begin{array}{r}1.8 \\
24.5 \\
26.4\end{array}$ & $\begin{array}{l}14.4 \\
33.4 \\
13.7\end{array}$ & $\begin{array}{r}47.6 \\
9.4 \\
2.6\end{array}$ \\
\hline $\begin{array}{l}\text { di } \\
\text { hy } \\
\text { ol }\end{array}$ & $\begin{array}{r}0.4 \\
21.4 \\
12.5\end{array}$ & $\begin{array}{r}19.7 \\
14.7 \\
7.0\end{array}$ & $\begin{array}{r}21.8 \\
16.0 \\
5.7\end{array}$ & $\begin{array}{r}12.8 \\
18.9\end{array}$ & 15.3 \\
\hline $\begin{array}{l}m t \\
i l \\
\text { ap }\end{array}$ & $\begin{array}{l}1.4 \\
1.2 \\
0.3\end{array}$ & $\begin{array}{l}1.5 \\
1.3 \\
0.2\end{array}$ & $\begin{array}{l}1.9 \\
1.5 \\
0.2\end{array}$ & $\begin{array}{l}1.8 \\
1.9 \\
0.4\end{array}$ & $\begin{array}{l}1.0 \\
1.2 \\
0.4\end{array}$ \\
\hline
\end{tabular}

Averages of $\mathrm{H}_{2} \mathrm{O}$-free analyses. $\mathrm{N}$ : number of samples

Molecular norm $\left(\mathrm{Fe}_{2} \mathrm{O}_{3} / \mathrm{FeO}=0.15\right)$
A. basal unit
D. flow 52
B. aphyric unit (excl. D and E)
E. red flow-unit at section 26
C. porphyritic unit

nature of the basal unit which contrasts with the subaerial nature of the aphyric and porphyritic units.

Trace element analyses are currently being carried out on the 59 samples from the ZigZag Dal Basalt, and will be discussed at a later date.

\section{Conclusions}

The deposition of the Zig-Zag Dal Basalt began with subaqueous volcanism which may have persisted during formation of the entire basal unit. After a short period of dolomite and sandstone deposition, the remaining $1200 \mathrm{~m}$ of the Zig-Zag Dal Basalt were deposited, mainly as a sequence of thick, almost certainly subaerial flows. This period of rapid effusion of large volumes of lava was interupted by an interval with less volcanic activity, during which up to $250 \mathrm{~m}$ of the underlying basalt was removed by erosion, and, locally, sediments and tuffs were deposited between the flows. As the basalt sequence occupies a trough 

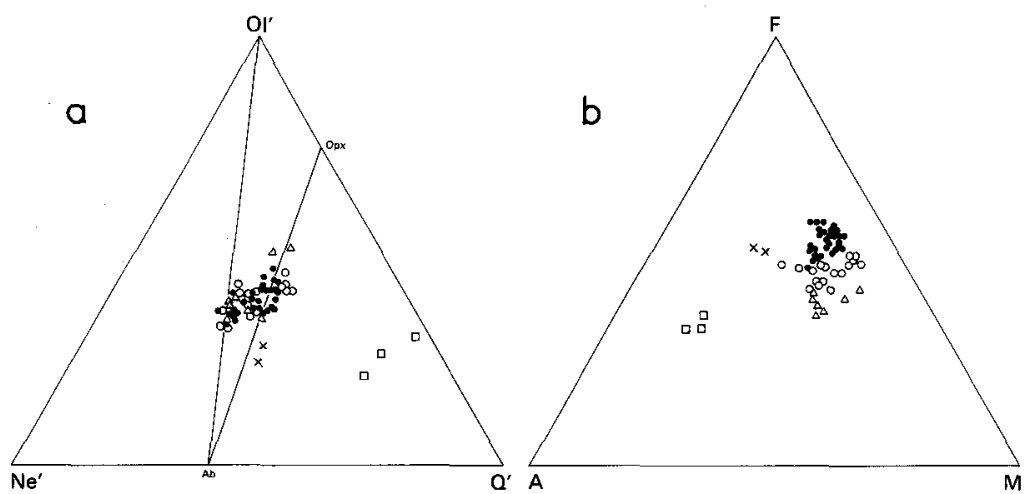

Fig. 13a. $\mathrm{Ol}^{\prime}-\mathrm{Ne}^{\prime}-\mathrm{Q}^{\prime}$ projection of the Zig-Zag Dal Basalt. Molecular norm $\left(\mathrm{Fe}_{2} \mathrm{O}_{3} / \mathrm{FeO}=0.15\right)$. $\mathrm{Ne}^{\prime}$ $=$ ne $+3 / 5 \mathrm{ab} ; \mathrm{Q}^{\prime}=\mathrm{qz}+2 / 5 \mathrm{ab}+1 / 4 \mathrm{hy} ; \mathrm{Ol}^{\prime}=\mathrm{ol}+3 / 4 \mathrm{di}$. Triangles: basal unit. Circles: aphyric unit. Dots: porphyritic unit. Crosses: flow 52. Squares: Red flow-unit (rhyolite) at section 26 (see text for explanation).

Fig. 13b. AFM plot of the Zig-Zag Dal Basalt. Symbols as in fig. 13a.

shaped basin which has been peneplained at the top, it must be concluded that after the termination of, and possibly during, the volcanic activity the central part of the basalt area underwent subsidence, after which the area was subjected to a long period of erosion. This erosion probably removed all of the basalt lying east and west of the present distribution area, before the deposition of the overlying basal sandstone association of the Campanuladal Formation.

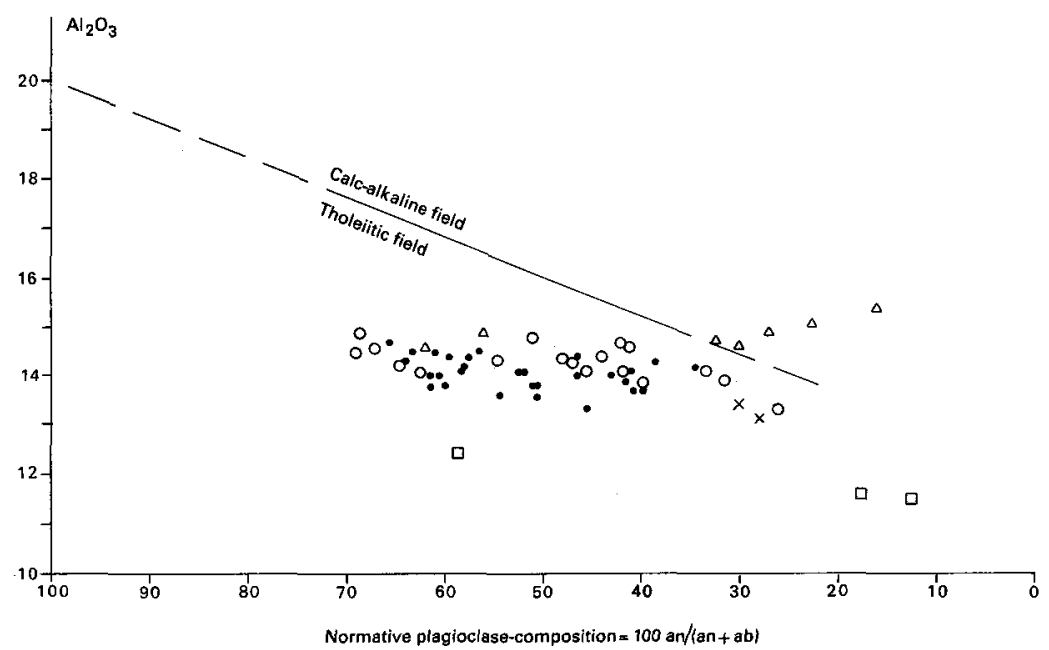

Fig. 14. Plot of wt $\% \mathrm{Al}_{2} \mathrm{O}_{3}$ versus normative (molecular) plagioclase composition: 100an/(an+ab) of the Zig-Zag Dal Basalt. Symbols as in Fig. 13a. 
The main body of the Zig-Zag Dal Basalt is composed of basalt of olivine-tholeiitic magma type. There are two exceptions: one flow in Mylius-Erichsen Land is composed of trachyandesite and a red flow-unit (max. $100 \mathrm{~m}$ thick) in J. C. Christensen Land is composed of potassium-rich rhyolite. The Zig-Zag Dal Basalt, which is probably genetically related to the underlying intrusive dolerites, is a typical tholeiitic flood basalt and as such belongs to some of the oldest deposits of this basalt type.

\section{References}

Clemmensen, L. B. 1979: Notes on the palaeogeographical setting of the Eocambrian tillite-bearing sequence of southern Peary Land, North Greenland. Rapp. Grønlands geol. Unders. 88, 15-22.

Haller, J. 1971: Geology of the East Greenland Caledonides. London: Interscience Publishers, 413 p. Håkansson, E. 1979: Carboniferous to Tertiary development of the Wandel Sea Basin, eastern North Greenland. Rapp. Grønlands geol. Unders. 88, 73-83.

Irvine, T. N. \& Baragar, W. R. A. 1971: A guide to the chemical classification of the common volcanic rocks. Can. J. Earth Sci. 8, 523-548.

Jepsen, H. F. \& Kalsbeek, F. 1979: Igneous rocks in the Proterozoic platform of eastern North Greenland. Rapp. Grønlands geol. Unders. 88, 11-14.

Streckeisen, A. \& Le Maitre, R.W. 1979: A chemical approximation to modal QAPF classification of the igneous rocks. Neues. Jb. Miner. Abh. 136(2), 169-206. 